\title{
Viability and location of Microdochium albescens in irrigated rice seeds produced in pre-germinated cropping system
}

\author{
Bruno Tabarelli Scheidt ${ }^{1} \oplus$, Juliano Berghetti ${ }^{1} \oplus$, Ricardo Trezzi Casa ${ }^{2} \oplus$, Flávio Chupel Martins ${ }^{3} \mathbb{\oplus}$,

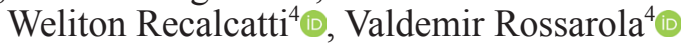

\begin{abstract}
${ }^{1}$ Doutorandos do programa de Pós-Graduação em Produção Vegetal (PPGPV), Universidade do Estado de Santa Catarina (UDESC), CEP: 88520000, Lages, SC, Brasil; ${ }^{2}$ Professor do PPGPV-UDESC, Universidade do Estado de Santa Catarina (UDESC), CEP: 88520-000, Lages, SC, Brasil; ${ }^{3}$ Mestrando do PPGPV-UDESC, Universidade do Estado de Santa Catarina (UDESC), CEP: 88520-000, Lages, SC, Brasil; ${ }^{4}$ Bolsista de Graduação (UDESC-CAV), CEP: 88520-000, Lages, SC, Brasil.
\end{abstract}

Autor para correspondência: Bruno Tabarelli Scheidt (brunotabarelli.s@hotmail.com).

Data de chegada: 27/04/2020. Aceito para publicação em: 04/11/2020.

$10.1590 / 0100-5405 / 237223$

\section{ABSTRACT}

Scheidt, B.T.; Berghetti, J.; Casa, R.T.; Flávio Martins, C.; Recalcatti, W.; Rossarola, V. Viability and location of Microdochium albescens in irrigated rice seeds produced in pre-germinated cropping system. Summa Phytopathologica, v.47, n.1, p.57-59, 2021.

The aims of this study were to quantify the viability of Microdochium albescens in irrigated rice seeds stored during the time between harvests and to quantify its incidence in the seed structures. Samples of irrigated rice seeds of the cultivars SCS122 Miura and SCS121 CL were monthly collected and stored during the time between harvests 2018/19. Pathology analysis and viability quantification were performed in the laboratory. The location of the fungus in the seeds was determined by separating lemma, palea, endosperm and embryo, with subsequent disinfestation and sowing in culture medium. The fungus M. albescens showed $77.8 \%$ seed storage viability for nine months, considering the average of lots and cultivars. Average incidence was $48 \%$ in the lemma, $43.7 \%$ in the palea, $24.7 \%$ in the endosperm and $20.7 \%$ in the embryo. The fungus M. albescens remains viable in rice seeds between harvests, while mycelium is detected at a higher incidence in the external tissues of caryopsis.

Keywords: Oryza sativa, fungi, seed quality, production systems

RESUMO

Scheidt, B.T.; Berghetti, J.; Casa, R.T.; Flávio Martins, C.; Recalcatti, W.; Rossarola, V. Viabilidade e localização de Microdochium albescens em sementes de arroz irrigado produzidas no sistema de cultivo pré-germinado. Summa Phytopathologica, v.47, n.1, p.57-59, 2021.

O objetivo deste trabalho foi quantificar a viabilidade de Microdochium albescens em sementes de arroz irrigado armazenadas durante a entressafra e quantificar sua incidência nas estruturas de sementes. Foram coletadas mensalmente amostras de sementes de arroz irrigado dos cultivares SCS122 Miura e SCS121 CL, armazenadas durante a entressafra 2018/19. A análise de patologia e quantificação de viabilidade foram realizadas em laboratório. A determinação da localização do fungo nas sementes foi quantificada separando- se lema, pálea, endosperma e embrião, com subsequente desinfestação e semeadura em meio de cultura. O fungo M. albescens apresentou durante nove meses viabilidade de armazenamento de sementes de $77,8 \%$, considerando-se a média dos lotes e cultivares. A incidência média na lema foi de $48 \%$, pálea $43,7 \%$, endosperma $24,7 \%$ e embrião $20,7 \%$. O fungo M. albescens mantém a viabilidade em sementes de arroz na entressafra e o micélio é detectado com maior incidência nos tecidos externos da cariopse.

Palavras-chave: Oryza sativa, fungos, qualidade de sementes, sistemas de produção.

Occurrence of diseases restricts the production of rice grains and seeds. In the state of Santa Catarina, Brazil, brusone (Pyricularia oryzae Cav.) is still considered the major disease (11), however, there are increasing reports of leaf scalding intensity caused by Microdochium albescens (Thüm.) syn. Microdochium oryzae; Gerlachia oryzae (Hashioka and Yokogi) (8).

Microdochium oryzae infects leaves and sheaths, but seed infection is also important because it reduces seed germination and seedling vigor (9). Under room conditions, $M$. oryzae can survive for three to 18 months in stored rice seeds (10). All parts of the rice seed are infection sites for M. oryzae (6), but defining the precise location of the pathogen can help determine the effectiveness of seed treatments (3).

The aims of this study were to quantify the viability of $M$. albescens in irrigated rice seeds stored during the time between harvests and to quantify its incidence in the seed structures.

Normally, the time between harvests of irrigated rice in southern Brazil corresponds to approximately six to seven months. However, this study was carried out for nine months, from March to November 2018. Eight seed lots of irrigated rice of the cultivars SCS122 Miura (7/8/12/14) and SCS121 CL (404/407/408/410) were used, which were naturally infected by the fungus $M$. albescens. The seeds were supplied by "Cooperativa Regional Agropecuária Vale do Itajaí" (CRAVIL), Santa Catarina, Brazil.

The seed samples were stored in $25 \mathrm{~kg}$ polypropylene bags, supported by pallets, inside masonry warehouses with partial control of temperature, air humidity and natural ventilation. The collection and homogenization of samples followed the requirements recommended by "Rules for Seed Analysis" (RSA) (2). The seed samples of the different cultivars were disinfected in sodium hypochlorite solution (1\%), washed in sterile water and allowed to dry on filter paper. Seeds were sown in acrylic plates containing Potato-Sucrose-Agar + Antibiotic (PSA + A) culture medium with four replicates of 100 seeds per sample, totaling 400 seeds per treatment, and kept in a growth chamber, at $25 \pm 2{ }^{\circ} \mathrm{C}$ and $12 \mathrm{~h}$ photoperiod, for seven days. 
Identification of $M$. albescens infected seeds was performed under stereoscopic magnifying glass and optical microscope so that the reproductive structures of the pathogen could be observed. The viability of $M$. albescens was evaluated every 30 days.

Data on the incidence of $M$. albescens in seeds underwent analysis of variance (Tukey test, $\mathrm{p}<0.05$ ). Results of the relationship between $M$. albescens incidence and storage time were subjected to regression analysis. The viability of the fungus was calculated according to the formula:

$$
V(\%)=\left[\frac{i x 100}{I}\right]-100\left[\frac{i x 100}{I}\right]-100
$$

Considering "V" the viability of the fungus at the end of the storage period, " $i$ " the initial incidence, and "I" the final incidence of the fungus in each cultivar and plot.

To study the location of the fungus in the seed, two lots were used of the cultivars SCS121 CL and SCS122, which had 400 seeds removed per lot and their lemma, palea, endosperm and embryo separated. Subsequently, the structures were disinfected in sodium hypochlorite solution (1\%), washed in sterile water, allowed to dry on filter paper and sown on acrylic plates containing PSA + A culture medium, totaling four replicates of 100 structures per cultivar in a completely randomized design.

The seeds were kept in a growth chamber, at $25 \pm 2{ }^{\circ} \mathrm{C}$ and $12 \mathrm{~h}$ photoperiod, for seven days. Identification of M. albescens was performed as described for the previous experiment. The obtained data were subjected to analysis of variance and means comparison test (Tukey test, $\mathrm{p}<0.05$ ). Statistical analyzes were carried out with the statistical programs SISVAR 5.6 (4).

There was a significant reduction in the detection of the fungus $M$. albescens as the storage period increased (Table 1). For seeds of cultivar
SCS121 CL, the average incidence reductions from the beginning to the end of storage were from $67.5 \%$ to $53.5 \%$ in lot 404 , from $66.0 \%$ to $48.0 \%$ in lot 407 , from $65.5 \%$ to $53.5 \%$ in lot 408 , and from $72.0 \%$ to $47.0 \%$ in lot 410 (Table 1 ).

For seeds of cultivar SCS122 Miura, there was an average incidence reduction from $63.0 \%$ to $52.0 \%$ in lot 7 , from $61.5 \%$ to $52.0 \%$ in lot 8 , from $68.5 \%$ to $48.0 \%$ in lot 12 , and from $71.0 \%$ to $61.0 \%$ in lot 14 (Table 1).

Considering $100 \%$ viability of $M$. albescens in the first evaluation, at the end of storage $77.8 \%$ viability was observed for the average of all lots and cultivars (Table 1). According to Telles Neto (12), when wheat seeds are stored for 12 months the incidence of the fungus Fusarium graminearum can reach zero. In the present study, $M$. albescens almost did not lose its viability during the nine months of storage (Table 1). Sanchez et al. (7) observed the presence of M. oryzae in rice seeds during two years of storage.

Analyzing the seeds of cultivars SCS121 CL and SCS122 Miura, $M$. albescens showed $74.7 \%$ and $80.8 \%$ viability, respectively, at the end of storage (Table 1). Results show that M. albescens survives by infecting irrigated rice seeds stored at room temperature from beneficiation to sowing in the southern region of the country.

The four seed structures of the two cultivars were infected with M. albescens (Table 1). There was no statistical difference between cultivars, however, there was a difference between components. The location of the fungus is considered most important in the transmission process (1).

When the lemma was separated from the palea, there was no difference between them, however, they differed statistically from the endosperm and the embryo. Mean infection was $48 \%$ in lemma, $43.7 \%$ in palea, $24.7 \%$ in endosperm and $20.7 \%$ in embryo (Figure 1). Manandhar (5) reported an average M. oryzae infection of $5.8 \%$ in

Table 1. Viability of Microdochium albescens in irrigated rice seeds during storage in Seed Processing Units at "Cooperativa Regional Agropecuária Vale do Itajaí", Rio do Sul, Santa Catarina State, Brazil.

\begin{tabular}{|c|c|c|c|c|}
\hline Cultivar & Lot & $\begin{array}{c}\text { Initial } \\
\text { Incidence }\end{array}$ & $\begin{array}{c}\text { Final } \\
\text { Incidence }\end{array}$ & $\begin{array}{c}\text { Final } \\
\text { Viability } \\
\end{array}$ \\
\hline SCS121 CL & 404 & 67.5 & 53.5 & 79.3 \\
\hline SCS121 CL & 407 & 66.0 & 48.0 & 72.7 \\
\hline SCS121 CL & 410 & 72.0 & 47.0 & 65.3 \\
\hline Average & & 67.8 & 50.5 & 74.7 \\
\hline SCS122 Miura & 7 & 63.0 & 52.0 & 82.5 \\
\hline SCS122 Miura & 14 & 71.0 & 61.0 & 85.9 \\
\hline Average & & 66.0 & 53.3 & 80.8 \\
\hline Overall Average & & 66.9 & 51.9 & 77.8 \\
\hline
\end{tabular}




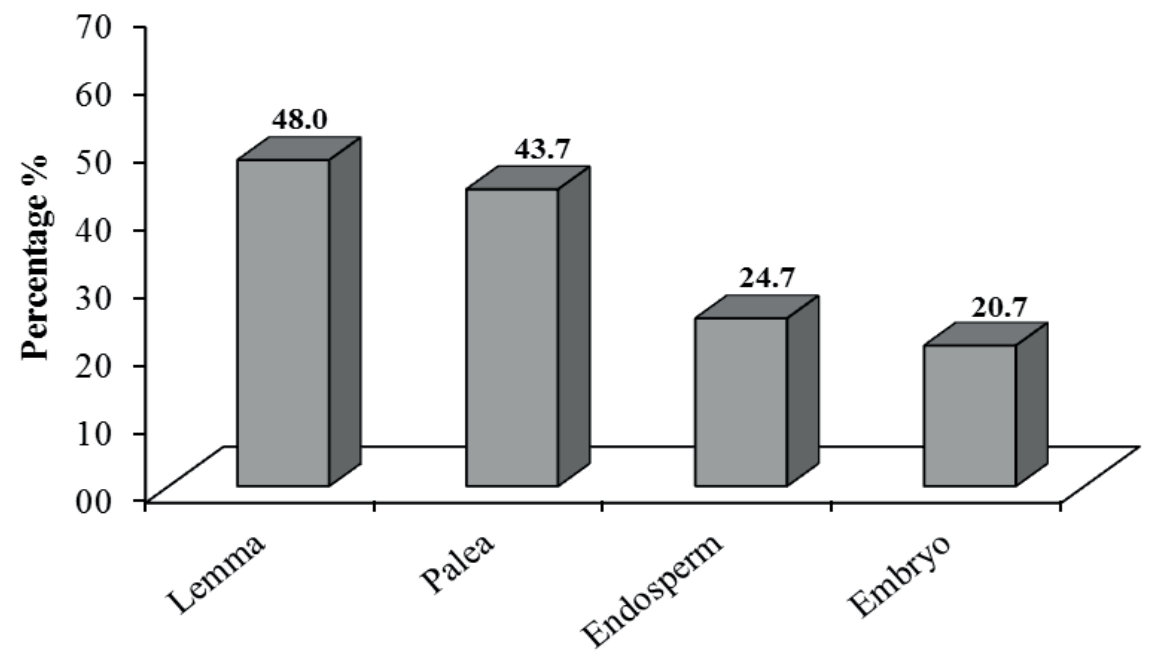

Figure 1. Average incidence of Microdochium albescens in lemma, palea, endosperm and embryo for SCS121 CL and SCS122 Miura cultivars. *Significant at $\mathrm{p}<0.05$ level, according to Tukey test.

endosperm, $4.3 \%$ in lemma, $2.7 \%$ in basal glumes, $1.8 \%$ in palea and $0.9 \%$ in embryo.

This is the first study analyzing the viability and location of $M$. albescens in irrigated rice seeds in Brazil and serves as a basis for future research related to germination, vigor, transmission and control strategies, whether chemical or biological.

\section{ACKNOWLEDGEMENTS}

Thanks to "Coordenação de Aperfeiçoamento de Pessoal de Nível Superior” (CAPES), Brazil, code 001.

\section{REFERENCES}

1. Agarwal, V.K; Sinclair, J.B. Principles of seed pathology. 3rd ed. Boca Raton: CRC Press, 1997. 555p.

2. Brasil. Ministério da Agricultura, Pecuária e Abastecimento. Secretaria de Defesa Agropecuária. Regras para análise de sementes. Brasília, DF: MAPA/ACS, 2009. 395p.

3. Faiad, M.G.R.; Machado, J.C.; Vieira, M.G.G.C.; Cornelio, V.M.O. Efeitos e transmissibilidade de Gerlachia oryzae (Hash. and Yok.) Gams em sementes de arroz (Oryza sativa L.). Ciência e Prática, v.17, n.4. p.357-362, 1993.

4. Ferreira, D.F. Sisvar: a computer statistical analysis system. Ciência e Agrotecnologia, Lavras, v.35, n.6. p.1039-1042, 2011. Available at: $<\mathrm{http}$ ://dx.doi.org/10.1590/S1413-70542011000600001>. Accessed on: 25 April 2020.

5. Manandhar, J.B. Isolation of Microdochium oryzae and Pinatubo oryzae from rice seeds and their survival on stored seeds. European Journal of Plant Pathology, v.105, p.139-145, 1999. Available at: < link.springer.com/ article/10.1023/A:1008765523465>. Accessed on: 15 June 2020.
6. Mia, M.A.T.; Saffeulia, K.M.; Shetty, H.S. Seed-borne nature of Gerlachia oryzae, the incitant of leaf scald of rice in Karnataka. Indian Phytopathology, v.39, p.92-93, 1986.

7. Sanchez, L.M.; Estrada, B.A.; Nuque, F.L. Seed transmission of Rhynchosporium oryzae. International Rice Research Newsletter, v.4, n.6, p.9-10, 1979 .

8. Scheidt, B.T.; Berghetti, J.; Martins, F.C.; Casa, R.T.; Recalcatti, W.; Rossarola, V.; Vieira, J.J.A.L. Fungi on irrigated rice seeds produced in the pre-germinated system in the Alto Vale do Itajaí region, Santa Catarina state, Brazil. Ciência Rural, Santa Maria, v.50, n.8, p.e20190903, 2020. Available at: $<$ http://www.scielo.br/scielo.php?script=sci_arttext\&pi$\mathrm{d}=\mathrm{S} 010384782020000800151 \& \operatorname{lng}=\mathrm{en} \& \mathrm{nrm}=\mathrm{iso}>$. Accessed on: 30 June 2020.

9. Singh, A.S; Sen Gupta, P.K. Effect of light on growth, sporulation and spore germination of Rhynchosporium oryzae the causal organism of rice leaf scald. Phytopathologia Mediterranea, v.23, n.1, p.65-66, 1985. Available at: $<$ https://www.cabdirect.org/cabdirect/abstract/19851305016>. Accessed on: 18 April 2020.

10. Singh, A.S; Sen Gupta, P.K. Role of various sources on the perpetuation of the rice leaf scald pathogen, Rhynchosporium oryzae. Indian Phytopathology, New Delhi, v.39, n.4, p.521-525, 1986.

11. Sosbai. Arroz irrigado: recomendações técnicas da pesquisa para o Sul do Brasil. In: Reunião Técnica da Cultura do Arroz Irrigado, 32., 2018, Farroupilha. Anais. Cachoeirinha: Sociedade Sul-Brasileira de Arroz Irrigado, 2018. p.2005.

12. Telles Neto, F.X.B.; Reis, E.M.; Casa, R.T. Viabilidade de Fusarium graminearum em sementes de trigo durante o armazenamento. Summa Phytopathologica, Botucatu, v.33, n.4, p.414-415, 2007. Available at: http://dx.doi org/10.1590/S0100-54052007000400017. Accessed on: 16 April 2020. 